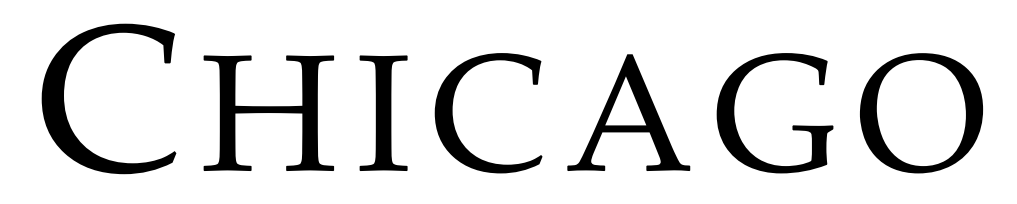

John M. Olin LAW \& Economics Working PAPER No. 204

(2D SERIES)

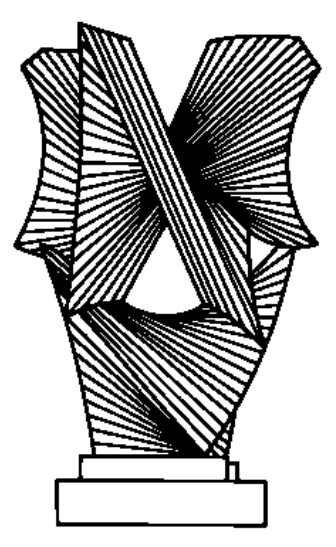

\title{
Liberty versus Property? \\ Cracks in the Foundations of Copyright Law
}

\author{
Richard A. Epstein \\ THE LAW SCHOOL \\ THE UNIVERSITY OF CHICAGO
}

April 2004

This paper can be downloaded without charge at:

The Chicago Working Paper Series Index: http://www.law.uchicago.edu/Lawecon/index.html and at the Social Science Research Network Electronic Paper Collection:

http://ssrn.com/abstract_id=529943 


\title{
Liberty versus Property? Cracks in the Foundations of Copyright Law
}

\author{
Richard A. Epstein ${ }^{*}$
}

\begin{abstract}
Many modern intellectual property scholars have argued that the creation of patents and copyrights, for inventions and writings, respectively, should be resisted on the ground that these forms of property necessarily infringe ordinary forms of liberty, in contrast to property that is found in tangible things. This article rejects that claim by showing how property conflicts with liberty in both settings, but that the different configurations of rights observed in these various areas is defensible on the ground that the loss of liberty for all persons is, to the extent that human institutions can make it, compensated by the increased utility generated by the various property rights in question. The appropriate approach to intellectual property is not abolition but finetuning in an effort to increase the gains from intellectual property generally.
\end{abstract}

The purpose of this paper is to recanvass what is surely old and familiar territory about the defenses, if any, that can be made for various forms of intellectual propertyand for the purposes of this conference, particularly copyright - as a matter of both natural law and utilitarian theory, broadly conceived. In dealing with this issue, it is important to note that within the Lockean tradition, the function of representative government is to protect the lives, liberties and estates of the individuals who, as subjects or citizens, are subject to the exercise of state power. ${ }^{1}$ There is little doubt that this formulation of the matter has exerted profound influence over the structure of American thought and constitutionalism. For instance, it is not necessary to look any further than

\footnotetext{
*James Parker Hall Distinguished Service Professor of Law, The University of Chicago; The Peter and Kirsten Bedford Senior Fellow, The Hoover Institution. My thanks to Eric Murphy for his valuable research assistance. An earlier version of this paper was presented at the Progress and Freedom Foundation Conference on Intellectual Property held in Washington D.C. on June 10, 2003, and at workshops at the University of Chicago, Fordham and Stanford Law Schools.

${ }^{1}$ John Locke, Of Civil Government: SECOND TREATISE ch. IX, \ 123 (1689) (“This [the insecurity of a state of nature] which, however free, is full of fears and continual dangers; and it is not without reason that he seeks out and is willing to join in society with others, who are already united, or have a mind to unite, for the mutual preservation of their lives, liberties and estates, which I call by the general name, property.").
} 
the two constitutional commands that provide that no individual be deprived (by either state or national government) of life, liberty or property without due process of law. ${ }^{2}$ For these purposes there are two elements of this formulation that deserve some brief mention. First, the phrase "without due process of law" has been long, if controversially, understood to cover situations in which individuals are deprived of life, liberty or property without just compensation. ${ }^{3}$ In this regard, the due process clauses mirror the more specific language of the takings clause, which provides "nor shall private property be taken for public use, without just compensation." ${ }^{4}$ But for our purposes, the more important claim within this clause is the ostensible parity between liberty and property in the constellation of constitutionality, and by implication, political values.

This yoking together of liberty and property has an obvious appeal for individuals who operate within the classical liberal tradition and view private property in its various manifestations as consistent with a regime of personal liberty. But notwithstanding the ease by which it is possible to run these two phrases together, it hardly follows that this coupling should be regarded as a necessary truth, to be denied only on pain of selfcontradiction. ${ }^{5}$ In fact a complete defense of both liberty and property requires a painstaking examination of the strength of each of these claims separately. Indeed, it requires some ingenuity to defend the ostensible parity between liberty and property when we deal with property in the tangible realm. The doubts about the parallelism between the two are, if anything, even more insistent in the realm of intellectual property.

\footnotetext{
${ }^{2}$ U.S. CONST. amends. V and XIV. The former applies to the national government, and the latter to the states.

${ }^{3}$ See Chicago, Burlington \& Quincy R.R. Co. v. Chicago, 166 U.S. 226, 239 (1897).

${ }^{4}$ U.S. CONST. amend. V.

${ }^{5}$ See, e.g., Tom G. Palmer, Are Copyrights Morally Justified?, in COPY FIghts: ThE Future OF Intellectual Property IN THE Information Age 43-44 (Adam Thierer \& Clyde Wayne Crews Jr. ed., 2002).
} 
Some commentators, such as James DeLong ${ }^{6}$ and Adam Mossoff, see a tight connection between natural law and intellectual property. ${ }^{7}$ But theirs is probably a minority position. There are many people who think that the current scope of the copyright laws sets up intellectual property in opposition to human liberty of speech and expression, such that in the contest between the two, the copyright law comes out second best behind these liberties. Thus, Tom Bell, a devoted natural rights Lockean, writes, acerbically: "More pointedly, copyright and patent protection contradict Locke's justification of property. By invoking state power, a copyright or patent owner can impose prior restraint, fines, imprisonment, and confiscation on those engaged in peaceful expression and the quiet enjoyment of their tangible property." Evidently, this sentiment is not confined solely to those that come from communitarian or New Deal traditions, who inherently have some uneasiness about the growth and expansion of intellectual property. There is also a strong undercurrent of discontent about the protection of intellectual property interests among those who purport to treat individual freedom as the highest good. The free software and the free copyright models show that there is much that unites the (anarcho-)libertarian right with the socialist or (anarcho-)libertarian left. ${ }^{9}$ Further, Lawrence Lessig and others have also echoed this sentiment with their calls for the recognition and promotion of the "creative commons." 10

\footnotetext{
${ }^{6}$ James V. DeLong, Defending Intellectual Property, in Copy FigHTS, supra note 5, at 17.

${ }^{7}$ Adam Mossoff, Locke's Labor Lost, 9 U. CHI. RoundTABLE 155, 155 (2002). For Mossoff's views on the natural law elements in the law of patents, see Adam Mossoff, Rethinking the Development of Patents: An Intellectual History, 1550-1800, 52 HASTINGS L.J. 1255 (2001).

${ }^{8}$ Tom W. Bell, Indelicate Imbalancing in Copyright and Patent Law, in COPY FIGHTS, supra note 5, at 4.

${ }^{9}$ See DeLong, supra note 6, at 17-18.

${ }^{10}$ See Lawrence Lessig, The Future of Ideas: The Fate of the Commons in a Connected World 86-99 (2001). See also Neil Weinstock, Copyright and a Democratic Civil Society, 106 YALE L.J. 283 (1996).
} 
The modern position thus seeks to place liberty in opposition to property and thereby to dissolve the bonds that in ordinary thought link the two together. I think that this effort to split the traditional alliance should be rejected, but by arguments that follow a route that calls into question much of Locke's labor theory of value. In this context, labor represents a form of liberty because it is a form of individual conduct that purports to establish the link between a particular individual and some particular resource, tangible or intangible.

In order to explore the nature of this tension as it applies to copyright, it is critical to understand how it plays out in connection with ordinary forms of property as well. Part I of this paper, therefore, is an examination of the tension between liberty and property within the natural law tradition of Locke who had, it should be noted, little or nothing to say about intellectual property as such. Once this basic understanding of the Lockean tradition is explicated, it becomes possible in the second portion of the paper to examine how the same tension between liberty and property plays out in connection with copyright, and by implication, other forms of intellectual property. In the end, it is largely proper to yoke together liberty and property, as has been done by our classical liberal forebears. However, the analytical path to achieving this result is far more tortuous than may appear at first reading.

Many of the people who oppose copyright protection do so because they think that intellectual property rights flunk where tangible property rights succeed. Namely, they argue that this failure is the result of the Lockean theory that has, as its essential justification for property rights, the three following steps: "Because a creator owns himself, 2) he owns his labor and, thus, 3) those intellectual properties with which, by 
dint of his creative acts, he mixes his labor." ${ }^{, 11}$ Yet it is just here that the argument falters. The Lockean syllogism does not take into account any system of property rights of the sort that Locke himself envisioned, either in one's self or in tangible externals. Rather, it becomes necessary to recast this theory in more consequentialist terms. Once that is done, the gulf between property rights in tangibles and property rights in intangibles is far narrower than these theorists believe. The set of justifications used in the former carries over to the latter. The only question that remains is how the differences in the nature of the resources in question, whether copyright or patent, (an issue that arises as well with tangible forms of property) require a distinctive configuration of property rights in the appropriate area. Therefore, we may have some justification for the limited terms of both patents and copyrights, and for their sharply different lengths. Further, we may understand the reasons for a privilege of fair use in copyright, but not in patent. But in thinking of these differences, we should not forget the close parallels between actions for trespass and those for infringement, or for the use of both damages and injunctions in both these areas. Intellectual property rights rest on some plausible but not infallible assumptions, but so too do property rights in land and water. Once we lay out the differences, ironically, we can understand the theoretical unity that cuts across these various areas. In accordance with this general plan, part I of this paper examines the natural law justifications for property in one's own person and in tangible objects. Part II of this paper carries the analysis over to the law of copyright.

\footnotetext{
${ }^{11}$ Bell, supra note 8 , at 3 .
} 


\section{LIBERTY, LABOR AND AUTONOMY.}

\section{Labor}

The starting point for the justification of tangible property is the famous statement of Locke that reads "Though the earth and all inferior creatures be common to all men, yet every man has a property in his own person; this nobody has any right to but himself. The labour of his body and the work of his hands we may say are properly his." ${ }^{2}$ Here, of course, the point is treated as a departure from the common pool norm for all that follows in his system. The most important deviations are the rules that speak about the expenditure of labor as a means to acquire private property by "mixing" one's labor with land or other external objects, which are said to be owned in common. ${ }^{13}$ However, this theory is subject to a wide range of important objections as it relates to liberty, property and their intersection. Many of these objections bear on the question of whether we should recognize property rights in general, or copyright in particular.

At the starting point, Locke's theory does not read like a paean to utilitarianism in particular or any species of consequentialism in general. Ironically, it does not appear to fall into the class of natural law theories that rest on some "backward looking" deontological claim, in which the question of right depends solely on all that has gone before, and not on those things that are likely to come afterwards. ${ }^{14}$ Nor is it clear that the claims can be conveniently slotted into theories of this sort. The most obvious point of criticism is that there is quite literally nothing that anyone has ever done to "deserve" the creation of ownership rights in his own person. Further, it does not matter what terms are

\footnotetext{
${ }^{12}$ Locke, supra note 1 , at ch. 5, $₫ 27$.

${ }^{13} I d$. ("Whatsoever, then, he removes out of the state that nature hath provided and left it in, he hath mixed his labour with, and joined to it something that is his own, and thereby makes it his own property.").

${ }^{14}$ See, e.g., Joel Feinberg, Justice and Personal Desert, in DoING AND DeSERVING; ESSAYS IN THE THEORY OF RESPONSIBILITY 81ff (1970).
} 
used, whether autonomy or self-ownership — assuming that some differences ride on the choice of terminology. The blunt truth is that these tangible things are gifts of nature, in the sense that no one has committed any form of labor to create them. The point receives its most forceful elaboration in the critiques that John Rawls has made of the claim that individuals own, or are otherwise entitled to their own (not normative, but descriptiveor so one assumes) talents. Rawls noted that it is "morally arbitrary" for any individual to be treated as the sole owner of his own talents because the determinants of their value lie at the random fortunes of birth and upbringing combined with the demand for these talents in some concrete social setting, which in some settings the talents are awarded enormously, but in others not at all. ${ }^{15}$

We can explore this counterargument to Locke on a number of grounds. First, many of our most important endowments from good health to good character and intelligence do depend upon the luck of genetic lottery, many of which no legal system can correct. For example, people born with fatal conditions, such as Tay-Sachs disease, will live short and unhappy lives no matter what form of income distribution is implemented in their favor. However, the Make-A-Wish Foundation does marvelous work for young persons with fatal maladies. It does not equalize fortunes across individuals, but at the same time it would be a mistake to adopt the posture of genetic determinism to the exclusion of social factors. Once we control for social factors, it seems indefensible to say, as a general matter, that across the board individuals' successes and failures depend in large measure on circumstances beyond their control. There are many people who are raised in adverse circumstances and achieve success in

\footnotetext{
${ }^{15}$ See JOHN RAWLS, A THEORY OF JUSTICE 310 (1971) (“A person's character depends in large part upon fortunate family and social circumstances for which he can claim no credit. The notion of desert seems not to apply to these cases.").
} 
life because they have, by dint of their own labor, developed the character and skills needed to allow them to succeed in the general world. By the same token, we all know many individuals who, as children, enjoyed every advantage of family and fortune only to make a mess of their own lives. It takes a good deal of confidence to believe that we have a strong knowledge of the determinants of individual success.

The Rawlsian response could come in the form of a regression of the sort that claims these personal virtues are derivative in large measure on the labor, care and comfort supplied by parents, often at great sacrifice to themselves. These individuals might have some claim of moral desert in virtue of what they have supplied their children. They have indeed engaged in activities that qualify under some "desert theory," looking backward to their past actions. But so what? If they choose to make gifts of services to their children, why cannot they transfer the fruits of their labor to their children in the same way that they leave them a share of stock or a family keepsake? Perhaps the answer lies in the idea that we do not allow individuals to make gifts of what they have created, even to their loved ones. There is a long tradition of propertied individuals such as Andrew Carnegie and Bill Gates who are in favor of very steep death taxes. If this is correct, the argument has shifted, at least in part, from justice in the acquisition of liberty and property to justice in transfer. The level of control that the state (i.e. other people) exercises over each individual becomes ever more extensive. If people do not own their own talents, they cannot transfer the fruits of their labor to anyone else either, or so it would appear.

The strongest opposition to the idea that individuals do not deserve to own their own labor comes, however, from this simple question: if I do not deserve the fruits of my 
labor, genetic endowments and parental assistance, then who does? If these elements are regarded as insufficient to establish a claim that each person owns his own labor and the fruits thereof, on a desert theory, they are surely not sufficient in any form or combination to allow any other person to claim those ownership rights in my labor. Reciprocally, I cannot claim ownership rights of any sort in their labor. After all, what possible desert do we have in the labor of others to which we have contributed nothing of any sort? Therefore, the rejection of the Lockean claim on individual self-ownership cannot be read as an argument that it fails the criterion of "desert," where the implicit subtext is that some other unspecified allocation passes that test. Quite the contrary, if the Lockean theory fails because it does not meet the standard of desert, then no other desertbased allocation is possible. Nor should we think otherwise. Nature (in the literal sense) has provided some freebies for us all. So long as there are unearned elements, it is not possible for all things of value to be earned under any version of the desert theory. The idea of desert becomes a siren and a sink-hole. We have to look elsewhere to justify any theory of property, private or common.

Unfortunately, this exacting use of the desert standard comes at a real cost because it drives a wedge between the everyday uses of the term desert and its philosophical deconstruction. "I deserved to get into college, obtain a job, win a prize, or indeed anything else in the world" is now to be treated as an otiose statement by individuals who just don't get the moral arbitrariness that clouds their ostensible personal achievements. Further, these critics leave completely undetermined just who should get the benefit of all the elements that are thought in combination to be insufficient to justify 
a claim on desert: genetic endowment, individual efforts, and parental instruction and concern.

There is a different way to look at the situation, which I think corresponds much more faithfully to ordinary sensibilities. No one doubts that the success in any given venture depends on some combination of individual effort and plain-old ordinary luck. Raoul Berger worked on an obscure history of impeachment, and lo and behold the Nixon impeachment loomed large just after the book was published. ${ }^{16}$ The book's success was a combination of luck and skill. However, no one in ordinary discourse thinks that he has to abandon the extra royalties that he obtained from the exceptional sales, especially to some undifferentiated group of individuals who could not be asked to contribute a dime if the book flopped totally from indifference. Our social attitude, therefore, is that any individual who contributes the labor to a particular project gets to keep the gains (subject of course to the contractual claims of others who joined with him in the project) even if these result in some portion from pure, old fashioned luck. ${ }^{17}$ The point that we make here is quite simply this: the usual skepticism about desert establishes indubitably that no one can make out a claim that 100 percent of any development is due to individual effort. It therefore follows that society allocates the output, subject to contractual claims to the individuals who contribute the lion's share of the material. In so doing, we reject any claim that the level of entitlement has to be "proportional" in some sense to the amount of effort that has been put into business. This proportionality cannot be satisfied even in robust competitive markets, which after all still allow-and to an

\footnotetext{
${ }^{16}$ RAOUL BERGER, IMPEACHMENT (1970).

${ }^{17}$ For my defense of this point, see Richard A. Epstein, Luck, 6 SoC. PHIL. \& POLICY 17 (1988).
} 
Austrian, indeed encourage - supracompetitive returns, at least in the short run, to those individuals able enough to create or occupy a new market niche. ${ }^{18}$

At this point, the argument may well veer to the consequentialist side of the line. Let there be no clear claim of desert that covers the full amount of the gain, then the issue arises - how ought that unearned gain be divided? The problem here is the inescapable question of joint creation. To assign that gain to people that had nothing to do with its creation shortchanges the original owner. To assign it to the creator allows him to keep the advantages of luck; yet by the same token it does not permit him to trench on the labor of any other individual. The great temptation here is to seek some form of apportionment, but that task is more easily said than done. To claim that some fraction of the gain should go to other people (say, in the form of a progressive tax on income) does not decide which individuals should be entitled to what share. For example, should there be a special credit for those who have taken care of the person in his formative years, and if so should it be above any market wage that they might have received for their efforts? Or should it go to individuals in the same neighborhood, city, state, nation, or world? The annoying fact of jurisdictional boundaries between nations could not slow down any cosmopolitan urge, at least at the moral plane on which it is thus far conducted.

At the practical level, two points are salient. First, this particular exercise has to be undertaken not only for this or that claimant, but for everyone who has ever received anything for his labor. Second, we cannot discharge this obligation by simply relying on some approximate test of income (with all its own problems of bunching and valuation) because there is absolutely nothing that says that individuals with the same levels of

\footnotetext{
${ }^{18}$ For an explanation of how other factors intrude, see John Christman, Entrepreneurs, Profits and Deserving Market Shares, 6 Soc. PHIL. \& POLICY 1 (1988).
} 
(earned or investment) income have benefited from the same level of luck. In sum, the effort to isolate "proportionate" contributions from luck and from effort falls apart because of the inability to conduct sensible measurements over countless individuals for countless periods. It would be so defective that it is in the long run interest of everyone to abandon any effort to isolate and reallocate the "unearned increment" (or decrement) that attaches to human labor. A rough and ready rule, therefore, that follows the naïve sense of desert works better in practice than any overt system that seeks to divert wealth to other individuals who are less deserving than the person whose labor created that wealth in question within the rules of the game. Hitmen need not apply.

At this point we can start to see the connection between the traditional natural appeal to theories of desert that rely on the labor theory of value, and the consequentialist situation that seeks, as I would have it, to create rules that in the long-run create win/win situations - call these Pareto improvements - for the vast run of the population. Each of us, ex ante, is better off waiving any inchoate claims against the labor of others on condition that they waive their claims in return. The purpose of this massive renunciation of weak class claims is not to guarantee some perfect allocation of the goods of the universe. It is the more mundane task to identify at low cost clear owners of labor so as to assure the security of investment and exchange that promotes long term productive wealth. It is not an accident that those who accept the self-ownership of individual labor tend to be strong devotees of the market system, because they see the deleterious effects that come from the perverse incentives that arise from any system that is blind to selfinterest and purports to operate on the principle "from each according to his ability, to each according to his need." It is only those who remain mired in philosophical doubt that 
see the ambiguities over desert as yet another nail in the coffin of market capitalism. ${ }^{19}$ Engaging in a case-by-case examination of the determinants of desert lets philosophical doubt sow administrative confusion in the countless practical decisions of each day. At this point, it is best to go back to an indirect form of consequentialism with roots in the earlier work of David Hume, ${ }^{20}$ who counseled against judging the soundness of social institutions by the way in which they play out in some individual case. These roots also appear in the earlier writings of John Rawls, who gave consequentialist judgments a larger role in evaluating social institutions, rather than looking solely at individual cases. ${ }^{21}$ For the sound operation of the legal and social system, we must understand why the larger practices make sense over the broad domain of cases, such that we can formulate a general rule that is not exposed to constant counter attack on a case-by-case basis.

Property

On balance there is sufficient reason to accept the general proposition that all individuals have exclusive rights to their own labor, at least as an initial presumption. The next question that needs to be asked is how this carries over to the case for individual ownership of property. Here again, the most common form of the philosophical argument stems from Locke. Locke saw the initial position as an uneasy mixture of individual ownership of one's own labor and the fruits thereof, and common ownership of the natural resources found in the world, which on his account God has given to all men in

\footnotetext{
${ }^{19}$ See, e.g., Christman, supra note 18, at 16(“The relevance of this [rejection of moral desert in labor], if nothing else, consists in dislodging another pillar in the already shaky moral foundation of freemarket capitalism.").

${ }^{20}$ See David Hume, A Treatise of Human Nature 502 (L.A. Selby-Bigge ed., Oxford Univ. Press 2nd ed. 1978) (1740).

${ }^{21}$ See John Rawls, Two Concepts of Rules, 64 Philosophical Review 3 (1955) (noting that it is sound to be a retributivist in cases of individual criminal offenses, even if it is important at the system level to understand the consequentialist (i.e. deterrence) justifications for various forms of punishment).
} 
common. ${ }^{22}$ But here again his account runs into a parallel difficulty to that which is raised in connection with the individual ownership of one's labor: how does one account for the unearned increment that goes to each individual who has by his labor taken something out of the common?

Here there are several ways in which to attack this question. One quick dismissal is based on a terminological objection. It is not possible to mix labor with property, so that Locke's argument fails as a misguided metaphor. This position is taken by Jeremy Waldron, who writes that the entire enterprise fails at this basic level. Most notably he contends that:

(P) Individual A mixes his labour with object $\mathrm{Q}$, seems to involve some sort of category mistake. Surely the only things that can be mixed with objects are other objects. But labour consists of actions, not objects. How can a series of actions be mixed with a physical object?

Yet that "impossibility" takes place all the time. In ordinary business transactions, it is common for one person to contribute labor and another capital to a joint enterprise. The mixing of labor and property can also happen by inadvertence or mistake. As I shall discuss later, the Roman Law and common law doctrines of merger all took as a common case the situation in which the labor of A applied to an object that was owned by B. The situation is common enough that one needs a set of rules to analyze it, which could not be done if the entire question of sorting out the relative contributions made no sense at all.

The real objections to this position must be more substantive. The first of these is to note that some portion of the problem lies in Locke's specification of the initial ownership position with respect to natural resources. Most concretely, he gives no

\footnotetext{
${ }^{22}$ Locke, supra note 1 , at ch. 5 , $₫ 26$.

${ }^{23}$ Jeremy Waldron, Two Worries About Mixing One's Labour, 33 PHIL Q 37, 407 (1984). This argument was brought to my attention in Mossoff, supra note 7, who criticizes the point on other grounds.
} 
account as to which, and if so, why resources should be regarded as owned in common. In this regard he is surely at odds with much of both the Roman and the common law tradition. It is instructive in this regard that Justinian's Institutes begins its discussion of property with a compilation of those natural resources that are indeed owned in common - the air, the water, and in the most complex form, the beach. ${ }^{24}$ But it is equally clear that Locke was not sensitive to the consequences that attach to common ownership. To be sure, he deals with the question of water briefly in his essay, but in general does not understand how the system of property rights works. At one point he observes as follows: "Though the water running in the fountain be every one's, yet who can doubt that in the pitcher is his only who drew it out." ${ }^{, 25}$ But this misses the point. Regimes of common ownership contain complex bars against the creation of private property by capture or occupation. It may well be that individuals can draw some water out of the river, but they could never claim the river as their own, by adding to it labor that allows them to separate it from others. The river is kept as a common in order to preserve its "going concern" value for transportation, fishing, recreation and the like. ${ }^{26}$ Likewise, Locke does no better when he writes that "Nobody could think himself injured by the drinking of another man, though he took a good draught, who had a whole river of the same water left him to quench his thirst." ${ }^{27}$ The question is not what the adverse consequence of one large draught would be, but rather the systematic consequences of multiple draughts, or worse diversions from the original river for irrigation and otherwise:

\footnotetext{
${ }^{24}$ J. INST. 2.pr.

${ }^{25}$ Locke, supra note 1, at ch. 5, 129.

${ }^{26}$ See Richard A. Epstein, Why Restrain Alienation?, 85 COLUM. L. REV. $970 \quad$ (1985).

${ }^{27}$ Locke, supra note 1, at ch. 5, ๆ 33.
} 
he ignores the problem of the common pool in his statement of the issue. ${ }^{28}$ Yet water law prevents individuals from taking as much water out of the common as they can. It follows, therefore, that the initial image of land, things, or animals as common property does not augur well for a system of individual ownership. Thus, it is instructive to note that the legal system in dealing with the questions of the rights to occupation (of land) and capture (of animals) does not start with the image of these resources as res commune. Rather, it treats each of them as a res nullius - a thing owned by no one- so that the occupation of land or taking of a chattel does not take any interest held by others in common.

To see the importance of not treating tangible property as communal in the initial position, it is useful to consider the law's treatment of those situations in which one person takes the land or chattels that another owns, and converts them to his own use. The classical legal texts on this subject all start with cases similar to the following example: I own a slab of marble that you take by mistake, from which you now carve a statue. Who owns the statue? What rights, if any, inhere in the nonowner? The answers to these cases are not easy, but for all their differences and variations, they never result in the Lockean solution that vests the entire ownership in the party whose labor improved material things owned by one or more other persons.

For these examples, it is only possible to indicate some of the key elements. The classical law often allows the person with the distinctive attribute (the sculptor) to keep the thing, while giving a substitute slab (or its cash equivalent) to the owner of the alternative input. However, partnerships are never created between the two parties: relationships of trust do not work well between individuals who are brought together by

\footnotetext{
${ }^{28}$ See Garret Hardin, The Tragedy of the Commons, 162 SCIENCE 1243 (1968).
} 
happenstance and chance. In essence a rule of forced exchanges dominates the matter, as the party who gets the thing is required to pay just compensation to the party who is required to surrender his interest in the thing, usually measured by its unimproved value. $^{29}$

Here we can convert these problems into the Lockean problem by assuming that the thing that one person takes is in fact owned by a group of other individuals in common. How then does the logic of the private law apply to this situation? The first cut into the problem is to distinguish between those people who take innocently from those who take in bad faith. The definition of an innocent party is not someone who commits no wrong. Rather, it is a person who takes and converts property out of justifiable ignorance of the property holdings of another individual. For instance, one who takes gold off of another's property, believing it to be his own property, is considered an innocent converter. ${ }^{30}$ The bad faith converter is, in contrast, one who takes with knowledge of the ownership claims of others.

In dealing with innocent conversions, we have the allocations noted above. The converter therefore should be treated as an owner of that segment taken, but he does not get the free and clear title that Locke attributes to him. In the first place, if he has taken more than his pro rata share, he must accept a lien on his property for the excess. Also, he must surrender all claims to the property that remains in the common. Yet no one thinks that the person who captures an animal or occupies land thereby suffers a diminution in his right to use rivers or breathe air. The model of partition and severance, which is sometimes used in cases of common property, does not explain how any individual owner

\footnotetext{
${ }^{29}$ See generally RiCHARD A. EPSTEIN, SIMPLE RULES FOR A COMPLEX WORLD 116-118 (1995).

${ }^{30}$ See, e.g., Maye v. Tappen, 23 Cal. 306 (1863).
} 
gets title free and clear by taking something from the common. That model also assumes that the person who takes property is an innocent converter. This assumption could only be correct if the rules in question allowed the universal right of separation, which is the very point in issue. One way to make that claim is to depart from the usual private law rules and to note that the claims of necessity allow the separation in question to take place, which of course is the line that Locke takes.

The case for private property is still weaker if we treat all individuals as bad faith converters of common resources because they know their legal status. The bad faith converter is an all around loser. First, he does not get to keep the thing. Also, when he returns it to its (common) owners, he does not receive any compensation for the labor or materials that he has added to the thing that he has taken. If therefore we follow the private law analogies on this subject, treating all natural resources as though they were owned in common has the unpalatable consequence that all individuals who (in bad faith) convert common property to private use have to return what they have taken, without compensation for their improvements. From there it is but an easy step to reach the conclusion that they can be enjoined from the taking, just as they could be enjoined from damming up the river, or blocking access to the ocean. Both of these examples are indeed common property, in law as well as in philosophy. This outcome is not the set of results that Locke had hoped to achieve by mixing private labor with commonly owned natural resources. However, it follows inexorably from his description of the initial ownership position. 
These problems are sidestepped by treating land, chattels and wild animals as res nullius. ${ }^{31}$ The shift in terminology has important consequences with respect to the aforementioned merger problem. It is no longer possible to say that the appropriation of an unowned object results in the conversion of the interest of any other person. Hence, the individual is now entitled to take as much as he pleases of these resources, and does not have to worry about the consequences that are imposed on other individuals. In fact, this position is the classical Roman and common law one.

The adoption of this position has with it several powerful advantages. For one thing, it allows the use of a quick and reliable test to identify the owner of each object, which in turn allows for orderly use, recombination and disposition of natural resources. The number of cases in which complications over hot pursuit will arise is small, notwithstanding the deserved celebrity of Pierson v. Post. ${ }^{32}$ In addition, this rule prevents giant sized holdout problems from taking place, the inevitable result if universal consent was needed to remove something from the commons. It is just that nightmarish spectacle that drove Locke to opt for his labor theory of value. ${ }^{33}$ However, he did so at a cost to his overall theory. The basic intuition behind the labor theory is that the huge bulk of the value of any given asset derives from the productive labor added to it, which is probably all that he meant when he used the metaphor "mixing" labor with natural resources. ${ }^{34}$ This analogy may be true of stony farmland, but it is obviously not true of the abundant Arabian oil.

\footnotetext{
${ }^{31}$ See, e.g., G. INST. 2.66; J. INST. 2.1.12.

${ }^{32} 3$ Cai. R. 175 (N.Y. Sup. Ct. 1805). The now celebrated dispute between Popov and Hayashi over the capture of Barry Bonds' record-breaking home run ball counts as one such case, but only because the San Francisco Giants did not stipulate the rule that governed its capture. See, Popov v. Hayashi, No. 400545, 2002 WL 31833731 (Cal. Super. Ct. Dec. 18, 2002).

${ }^{33}$ Locke, supra note 1 , at ch. 5, 128.

${ }^{34}$ See Mossoff, supra note 7, at 158-159.
} 
In addition, Locke also had to cope with the antecedent difficulty of how any individual came to have the right to add labor to objects in the first place, if he did not own them by initial possession. For instance, acorns must have received their owner when they were "picked up," and not at some later point when they were carried home, boiled or eaten. ${ }^{35}$ It is important to see how this potent example reverses the sequence of the labor theory of value. After the fact when the item is owned and improved, it is tempting to say that ownership should be complete because of the enormous labor that the owner expended on the object. However, the real task is to adopt a rule that requires as little labor as possible in order to perfect title to the acorn, so that the owner can be confident that he will be able, by holding on to the external object, to keep the benefit of the labor that he creates. To take the other position has adverse consequences. If ownership were acquired, for example, only when the acorns were boiled, this legal rule would foreclose the possibility of storing the acorns for later use, since title to them would still be precarious. Likewise, land would have to be developed (to the dismay of conservationists) for title to be perfected. The point of the mixing is to allow the addition of labor to natural resources to increase their value, and that objective is achieved by moving the point of acquisition forward to the earliest possible moment. Looking at the acorn will not do it; hot pursuit might well, and capture surely does. Locke in a sense has it all backwards. The purpose of the first possession rule is to allow for the easy acquisition of material things so that their owners will be in a position to expend labor on them. It makes no sense to demand the huge expenditures of labor as a precondition of ownership. Locke only alludes to that erroneous view because he wants to make the

\footnotetext{
${ }^{35}$ Locke, supra note 1 , at ch. 5, ๆ 28
} 
preexisting value of natural resources small relative to the labor used to improve them. ${ }^{36}$ That might be true in some cases, but not for all. Land that needs to be cleared for agriculture requires much hard labor, but land in which deep pools of oil are oozing out of the surface requires much less. I have little doubt that Adam Mossoff is correct when he reads the word mixing as a metaphor for productive labor. But the more telling objection is that this recasting of Locke's view does not save his theory, even against the example of the acorns. In contrast, the correct and simpler point is that taking something from the commons and holding it just marks off what one person has against another in a cheap way that gives notice, as possession often does, to the rest of the world as to the existence of the prior claim.

The movement from res commune to res nullius escapes the serious objections to the theory of combining labor with external objects, but standing alone it does not answer all questions that the philosophical skeptic can raise relating to the troubled status of private property. One line of objection is that this definition of property remains necessarily inconsistent with the broad definition of liberty that is part of the endowment of each person - the precise claim that is urged with copyright. That liberty includes the ability to go where one wills, and this right of movement is necessarily limited by the creation of any system of private property, which converts free movement into trespass. The point has been argued extensively by Robert Lee Hale and G.A. Cohen, ${ }^{37}$ both who see the creation of any law of trespass as a limitation, often unjustified, on individual freedom.

\footnotetext{
${ }^{36} I d$. at ch.5, $\uparrow 43$.

${ }^{37}$ Robert Lee Hale, Coercion and Distribution in a supposedly Non-Coercive State, 38 POL. SCIENCE Quart. 470 (1923); G.A. Cohen, Self-Ownership, Freedom And Equality 55-56 (1994). I have critiqued their positions at length in RICHARD A. EPSTEIN, SKEPTICISM AND FREEDOM: A MODERN CASE FOR CLASSICAL LIBERALISM 110-114, 132-138 (2003).
} 
The blunt truth is that this challenge cannot be turned aside by some pat analytical response. It is conceivable that we could treat land as a commons like water and thus prevent its permanent occupation by any one. Early nomadic tribes followed just this pattern. However, the reason we are not still in this primitive state are the enormous advantages from the privatization of land, without which no one would invest in permanent improvements at his own expense that could be snatched away by anyone. The short answer to the question of why the law confers private ownership of these resources is the same as it is for labor. It works to the long-term advantage of everyone behind a veil of ignorance, so that these limitations on liberty are justified by the gains that they yield from the social ownership of property. The losses that people suffer from exclusion are small compared to the gains that they get both from their ability to privatize their labor and from their ability to enter into trade with those who have engaged in privatization. It is for this reason that Blackstone, in dealing with the first possession rule, noted that it was the product of the "implied consent" of mankind. ${ }^{38}$ Clearly, the term "implied consent" is again asked to do too much work. From a modern perspective, he is really saying that from a social vantage point, the creation of private property through acquisition is a clear Pareto improvement over a world in which each person enjoys (as per some commons) a blockade position against everyone else. Once again we get a form of closet consequentialism in the articulation of our legal rules, which came out into the open with Harold Demsetz's short famous article on the functional justifications for the law of property. ${ }^{39}$

\footnotetext{
${ }^{38} 2$ William BLACKSTONe, COMMENTARIES *8

${ }^{39}$ Harold Demsetz, Toward a Theory of Property Rights, 57 Am. ECON. Rev. 347 (1967).
} 
All this, however, is not that transparent, for even if one adopts the first possession rule, one has to determine what counts as "possession" within the meaning of the rule. Here there is a largely forgotten literature today that asks why, or how, someone keeps possession of a thing after he no longer grasps it in his hand. ${ }^{40}$ In some cases, it makes sense to allow possessory interests of limited duration only. For example, the short term use is preferred in the case of those who make temporary huts on public beaches. The limited use is consistent with keeping the beach open for transportation in the way in which permanent structures are not. ${ }^{41}$ But once we leave the commons the situation is usually otherwise. As Bentham described in one of his famous passages, the situation of limited property rights is most unfortunate from just about everyone's vantage point because of the precarious nature of the possession that is so created.

There have been from the beginning, and there always will be, circumstances in which a man may secure himself, by his own means, in the enjoyment of certain things. But the catalogue of these cases is very limited. The savage who has killed a deer may hope to keep it for himself, so long as his cave is undiscovered; so long as he watches to defend it, and is stronger than his rivals; but that is all. How miserable and precarious is such a possession! If we suppose the least agreement among savages to respect the acquisitions of each other, we see the introduction of a principle to which no name can be given but that of law. A feeble and momentary expectation may result from time to time from circumstances purely physical; but a strong and permanent expectation can result only from law. That which, in the nature state, was an almost invisible thread, in the social state becomes a cable.

Property and law are born together, and die together. Before laws were made there was no property; take away laws and property ceases. ${ }^{42}$

In one sense it is clear that Bentham sought to set himself up in opposition to Blackstone, but in fact the two make exactly the same point. ${ }^{43}$ The theories of natural

\footnotetext{
${ }^{40}$ For the Roman treatment on this subject, see JOSHUA GETZLER, ROMAN IDEAS OF LANDOWNERSHIP, IN Land Law Themes and PersPectives (Susan Bright \& John Dewar eds., 1998), and BARRY Nicholas, AN InTRODUCTION TO ROMAN LAW (1962). For the common law approach, see POLlOCK \& WRIGHT, POSSESSION AT COMMON LAW (1888).

${ }^{41}$ See J. INST. 2.1.pr.

${ }^{42}$ JEREMY BENTHAM, THEORY OF LEGISLATION 112-113 (4th ed. 1882).
} 
rights in property cannot stand because the power of the state is needed to extend possession beyond the situations of actual control. The state that creates property can (by implication) limit its extent at will. But in fact his passage only establishes what the natural lawyers, as Blackstone forcefully argued, had long thought to be the inescapable conclusion of their own system. In Bentham's choice of problems, the above passage exhibits a remarkable continuity of thought. In fact, his example of the deer points in exactly the opposite direction of what he believed. Any culture could, should, and would develop this same norm in dealing with the property rights of its members. The most primitive sense of possession only covers the actual grabbing and holding on to an object. Such a rule is manifestly inconvenient because it means that legal possession ceases when the possessor loses his grip on what is handled. Only by degrees, the term possession is extended to cover those cases where the physical control is relaxed because of the intention to retain ownership. The point is critical not only as a linguistic matter, but because of the simple truth that many standard Roman and common law remedies were keyed to "possession"- only the possessor had standing to bring the suit in question. When, therefore, Bentham refers to "least agreement between savages," it is simply an elegant way of restating the implied consent argument in Blackstone and others. The rule that treats individuals as in what is sometimes term "constructive" possession of things that they do not continue to literally possess in their hands created such an enormous Pareto improvement that no one could oppose it from behind the veil of ignorance. Indeed, it is commonplace in both Roman and American law that the occupant of an estate need not prowl its boundaries to maintain a hold. Rather, "suffice it

\footnotetext{
${ }^{43}$ See 2 William Blackstone, Commentaries *3-4 (noting the inconvenience of the transient ownership).
} 
that he enters some part of the estate, but with the intent and awareness that thereby he seeks to possess the estate to its utmost boundaries." ${ }^{, 44}$ Nor is it hard to infer the intention to possess the entire estate. Individuals with a modicum of self-interest will claim all that the law allows them to achieve through unilateral action.

The last distinctive element of land is the rule that allows for acquisition of the surface to cover the rights to the earth (and minerals) below and the air above. Land is not two-dimensional, but it is not practicable in any way to require individuals to expend huge resources in order to stake out claims. Thus, we again encourage the private protection of some "unearned increment" because the key task of the system is to reduce the labor and complexity that is required to reduce natural things to private ownership. A legal regime that requires individuals to expend labor that is equal in value to the property acquired reduces the value of the property to zero. Any system that requires individuals to run through hoops in order to acquire these interests in property reduces their value pro tanto. Again, from an ex ante perspective, it is in society's best interest to have as few barriers to the creation of private ownership as possible, and not as many as could be imposed.

In the end, therefore, any exploration of the rules that govern the acquisition of property have the same feel as those that deal with liberty. In both cases, there is an unearned increment of talent or wealth that is not deserved under some strong theory of individual moral desert. That objection, however, carries little weight in the general case because, if true, it means that no one else could mount a claim based on desert either. Therefore, the best solution is to develop some cheap rule that allows individuals to mark off property as their own as cheaply as possible. It is better that the unearned increment

\footnotetext{
${ }^{44}$ Dig. 41.2.3.1 (Paulus).
} 
be held by someone, rather than it be lost in the morass of competition to acquire ownership. With both property and liberty there are limitations that may well make sense. For example, one major issue is the common pool problem, which results in the overhunting of certain forms of wild animals that at common law are subject to unlimited capture. But these limitations are not designed to set liberty in opposition to private property, nor to challenge the legitimacy of either. Rather, they are designed to continue the process of creating long-term social improvement by sensible incremental modifications of a system of property rights. These issues are not without their importance for the area of copyright, where they help to frame so much of the current debate over the subject.

\section{LIBERTY AND PROPERTY—THE SECOND CUT IN COPYRIGHT}

The second part of this paper is intended to show how the tension between liberty and property plays itself out in connection with the law of copyright. In most settings, the common understanding is that the case for the creation of copyrights is, if anything, weaker than it is for ordinary forms of property. The individual act of acquisition of land or chattel means that the general system of self-help allows individuals to both define and protect their individual property rights. It is easy to imagine how a system of property rights is natural, in the sense that it does not take any state agency to mark off the rights in question. In this view, the rights come from acquisition, and the sole function of the state is to provide protection for them with the use of public force administered by an executive branch and enforced by a set of impartial judges. We can leave the legislature all to one side. 
That solution is not possible with copyright. For while metes and bounds could work for land, and simple possession for most chattels, the only way to protect copyrights is through the creation of some system that allows for them to be posted and recorded, and that takes some form of state power. The demands on self-help are far greater in copyright than for real estate. With copyrights, one quite literally has to commit a trespass against another in order to make good on the claim. It is for this reason that the Supreme Court has repeatedly stated that there is no natural right to property, given that it is, in a sense that Bentham would approve, the creature of the state, for which it ascribes overtly utilitarian justifications. ${ }^{45}$ The view becomes more credible that copyrights come from the top down even if rights in land and chattels come from the bottom up. Thus, Tom Bell argues that copyrights should be denounced because they are totally creatures of the state. ${ }^{46}$

In another sense, the case for treating copyright and other forms of intellectual property under the natural rights framework is more attractive than this brief account suggests. The initial stumbling blocks for treating copyright with the natural rights theory of property are the following two: does a person own his own labor, and what happens when that labor is mixed with resources that are owned in common. On the first question there is nothing about the copyright situation that deviates from other uses of labor. The general argument in favor of strong protection of rights in one's labor carry through against any claims that some theory of desert pulls us in the opposite direction. It does not seem correct to say, as Tom Bell has written, that the labor-desert justification of property gives a creator clear title only to the particular tangible item in which he fixes

\footnotetext{
${ }^{45}$ See, e.g., Graham v. John Deere, 383 U.S. 1 (1966).

${ }^{46}$ See Bell, supra note 8 , at 3.
} 
his creativity - "not to some intangible wisp of the metaphysical realm." We do have a system of non-wispy copyrights at the present. While one might oppose their creation, the rights in question are capable of sale or licensing, are protected against confiscation and infringement, and are capable of valuation. One might as well give the same dubious description to ordinary contract rights, for which the government cannot take an assignment unless it is prepared to compensate the assignor for the loss of his entitlement.

To be sure, Locke did not offer any explicit treatment one way or the other of intellectual property rights, which adds to his charm. But it hardly follows that his theory has no implications for the area. Indeed the labor theory of acquisition seems, if anything, stronger here precisely because intellectual property does not require any form of "mixing" with tangible forms. Rather, these types of property appear to be the result of pure labor, which the creator, therefore, cannot keep because first possession of a tangible object allows him only to protect the paper on which the draft is written, rather than the draft itself. Yet by the same token, the author has not taken anything else out of the commons and so does not run into the joint contribution objections that undermine the power of the first possession rule for tangible objects. The only function of legal intervention here is to protect that investment in labor, without any expropriation.

In this regard, however, there is a second counter that must be met. It may well be that individuals do not pull material things out of rivers and woods when they work, but they do depend on a cultural commons of sorts for their inspirations and ideas. In light of this commons, it is possible to mount a desert-like attack on copyrights, as with other mental activity, by noting that all individuals are constantly subject to a wide range of external influences, which enrich their works. The argument thus goes that it is not 
possible to think that some unmediated and flawless market registers their intrinsic personal worth. Indeed, some believe the creation of the copyright monopoly is one of the factors that prevents the proportionate response of return to labor. ${ }^{47}$ If that point were true with respect to the making of widgets, it is certainly true as well of the nameless author of the essay "Of Widgets," whose success is parasitic on the inventors and fabricators of widgets. The information that is supplied depends on the contributions of large numbers of other individuals. The "author" is deconstructed into a vessel through which countless forms of influences are poured. Parental upbringing, education, literary influence, and the past recordation of popular events are all examples of these influences. How much credit could we give to Charles Dickens if his portrait of Wilkins Macawber in David Copperfield is based on his father? And how much if he has incorporated elements of the great writers of the past into his writing style without compensation or perhaps even acknowledgement?

The answer to the specific challenge is the same as it is in the general caseconfession and avoidance. There is little question that all these influences come to bear on the individual author. But by the same token, it is possible to locate in one person, or a small group of joint authors, the creative spark or hard effort that took these disparate influences and melded them into a coherent work, worthy of our attention. The others with whom the creator works can protect themselves by contract. The system of copyright ownership was right to fasten its attention on (un-deconstructed) authors, as the Constitution so requires. ${ }^{48}$ It thereby gives the entire claim to the one person who has contributed the lion's share to the finished product, with the precise intention of slighting

\footnotetext{
${ }^{47}$ See, e.g., Christman, supra note 18 , at 12 .

${ }^{48}$ U.S. CONST. art. $1, \S 8, \mathrm{cl}$. 3. ("To promote the progress of science and the useful arts, by securing for limited times to authors and inventors the exclusive right to their respective writings and discoveries.").
} 
the indirect contributions of other individuals to this product. Do we want to treat as an author any person who forbore from killing or maiming the author while engaged in his creative efforts? Or even those who were the creative inspiration to the person who did the writing? The constant emphasis of these indirect effects overlooks the simple point that the author of a copyrighted work contributes - dare we say in equal measure — back to the common pool by the creation of images that allow others to continue with their work as well. Thus, these contributors get implicit in-kind compensation for their contributions, in their ability to use the creator's works for their own creations. Therefore, so long as we think that the copyright law gives sensible incentives for the creation of new works, there is no reason to think that every dime of revenue has to be earned in order for all of it to be allocated to the author. Indeed in many cases, the "monopoly" element in the return is overstated because the exclusive rights often do not become economic monopolies, in light of the fierce competition for readers or listeners that is facilitated by the copyright law.

This basic frame of argumentation also carries over to the clear conflict between copyright and freedom of speech, which in its essential form is analogous to the conflict between liberty of movement and the trespass laws. Trespass law is useful for land only because of the network of public roads and waterways that allows for movement between various plots of private property. Similarly, we have a common domain of ordinary speech and language that is outside the scope of the copyright law, which facilitates the creation of the writings that are properly subject to protection under the statute. The legal monopoly conferred by a copyright or a patent need not translate itself into an economic monopoly so long as there are close substitutes, as there are for every new popular song 
that is released. As one wag (I know not who) put it, property and monopoly are not different sides of the same coin. They are the same side of the same coin. We cannot decide that copyrights present any social risks unless we think that they make barriers against the creation of new works. That risk, moreover, looks to me to be more critical to the patent law, especially with genetic materials, than it does to any song or musical work. No one has to use any particular song or story for a particular project, but can draw on a rich culture, including items that have fallen out of copyright protection. In contrast, it is quite difficult to conduct research on breast cancer unless one has access to the BRAC-I gene. Getting the right rules for this area is a difficult task. Everyone agrees that patent protection should be shorter than copyright protection. However, beyond that point there are deep, perhaps unbridgeable, differences of opinion, between those, like myself, who think that the problem is well handled by traditional doctrines and others who think, even more emphatically, quite the opposite. The lost use involved is of little consequence for any dynamic development of the arts, which need not be the case in patents. Copyright of course has implications for short-term use given that each song is still priced above marginal cost of production even in a competitive industry. Yet again, there is no reason to think that some undifferentiated interest in liberty is so strong as to snuff out any creation of property rights.

On balance, as with tangible objects, the pairing of liberty and property seems to survive, if it does not exactly prosper. One way to look at this element is to analyze the reception that copyright law has in connection with freedom of speech, where the constitutional doctrines in question are anything but moribund. In this case, the usual judicial view of the subject is the opposite of that found in the Lockean literature already 
quoted. Thus, for the Supreme Court freedom of speech begins at the point that the delineation of copyright protection leaves off, and this idea rests in a world in which intermediate or strict scrutiny is very much the order of the day. ${ }^{49}$ One way to solve this problem is to argue that the issue is one of definitions: copyright infringement is a wrong so that it cannot be justified under the First Amendment. However, to the serious analyst this counts as a form of question begging because the issue is in reality about whether Congress can create these rights at all. At one level that question seems otiose because of the explicit power to create copyrights found in Article I of the Constitution. But by the same token, it could be argued that the First Amendment requires that one justify the creation of the regime with reference to its purpose of the advancement of the useful arts. In the ordinary case, we could argue that this is indeed satisfied because the incentive gains from the creation of these exclusive rights justifies the restrictions on speech that are imposed.

Even that inquiry, however, leaves open the further question of whether the balance of trade is sufficiently out of whack in some specific cases so that the balance has to be rethought or redrawn. The most obvious point is whether the fair use privilege, as it relates to criticism and comment on literary works, is something that is required by the First Amendment, which I think ought to be the case, even if it is not at the present time. But the issue comes up in other contexts as well, especially in relation to the duration of copyright protection, which under the constitution has to be for limited times only. This case is one in which the use of a Constitutional phrase is far less preferable than the use of a number. It is in contrast to the use of the twenty-dollar figure in the Seventh Amendment, which was far less useful than no number at all. The Constitution could

\footnotetext{
${ }^{49}$ See, e.g., Harper \& Row Publishers Inc. v. Nation Enterprises, 471 U.S. 539 (1985).
} 
have picked anything from 1 to 1000 years (or different terms for patents and copyrights). This number would have been preferable because people would have known where they stood, and it would have avoided endless theorizing as to the purpose of so ill-formed a restriction. As long as discounting is taken seriously, the value of the future life of a copyright could vary anywhere from 10 percent to 99.9 percent of the value of the use. The vague constitutional provision gives no guidelines as to which of these extremes should be regarded as best.

In the general analysis, the first contrast between copyrights and real property is that there is no obvious reason to limit the duration of rights in real property. ${ }^{50}$ The long period of ownership spurs development; but since only one person can farm at any time, it does little to crimp utilization at the back end. With copyright, the possibility of multiple utilizations of the item, without exhaustion of its physical properties, allows for a realization of gain if the term is cut short. This gain is not found in real property, and makes copyright unique. But even here the point is not by any means decisive.

The calls for permanent copyright protection (but rarely for permanent patent protection because of how technology overtakes invention) have been raised in many quarters: Samuel Clemens ${ }^{51}$ for one, and most recently by my redoubtable colleagues Professor William Landes and Judge Richard A. Posner. ${ }^{52}$ This argument recognizes the costs of exclusion but does not find them conclusive. ${ }^{53}$ The source of the uneasiness in their work is a concern about the possible deterioration of valuable properties when

\footnotetext{
${ }^{50}$ For a discussion of the variation in property rights types, see Richard A. Epstein, Intellectual Property: Old Boundaries and New Frontiers (Addison C. Harris Lecture), 76 IND. L. J. 803 (2001).

${ }^{51}$ Samuel L. Clemens, Copyright in Perpetuity, 6 GreEN BAG 2d 109 2002).

${ }^{52}$ William M. Landes \& Richard A. Posner, Indefinitely Renewable Copyright, 70 U. CHI. L. REV. 471 (2003).

${ }^{53} I d$. at $475-484$.
} 
placed in the public domain. At one level, this state of affairs in the public domain should be regarded as a good because the public domain status of the asset creates two real advantages. First, it eliminates the transactions costs associated with various licensing and sales arrangements, such as identifying holders of valid rights, negotiating deals and the like. Second, it permits the brand management of the asset so that it does not, in some sense, suffer from overexposure or incompatible uses. That these points cannot be dismissed at the general level is evident from the Congressional mandate in the BayhDole Act, ${ }^{54}$ which calls on private parties who receive government grants to earnestly consider whether to take out patents on the fruits of their research. The great fear of this act is that items that are left in the public domain will languish because any developer of the idea will be undercut by future imitators who can supply the same or similar products at a far lower price.

The question one must ask is how do these things play out outside the patent field. In this regard, it is imperative to distinguish sharply between the tradename/ trademark/right of publicity cases. Strictly speaking, the branding exercise is at stake in the first two types of cases, and in some instances in the third type. Socializing the name or mark makes it worthless for anything but decoration because it will fail in its function to relate the item branded back to a single source. In the cases in which the right of publicity is used for the same purpose, it is subject to the same kind of rationale. This rationale does not apply to those who wish to perform as Elvis Presley look-alikes, and a strong case exists for bifurcating the right and allowing the protection to be of indefinite duration, when used for purposes of identification or branding.

\footnotetext{
${ }^{54} 35$ U.S.C. § 200 (2000).
} 
With the copyright system, however, the emphasis is not on branding but on performance, and here we do have extensive experience with materials that have fallen into the public domain. There are countless, often perverse, versions of Shakespeare that are produced everywhere today. The Shakespeare trust would probably not license some of these performances at all. Further, the trust would charge a hefty fee for the standard performances that they did license, and could easily place tight restrictions on the choice of sets, designs, actors and the like. Anyone is hard pressed to believe that Shakespeare's star has been dimmed by the calamities committed in his name, or that the world would be a better place if the obvious restrictions on use could be achieved with the blessing of the state. For those copyrighted works (treatises and casebooks, alas, for example) that need revisions on three-year cycles to stay current, the duration of a copyright is of little consequence. However, the duration issue only counts for the literary works that are immortal, and for these works, the original judgment that they be for terms is correct. Further, the terms should be significantly shorter than the life plus 50 years that is contemplated for new works today.

The question of duration is, of course, not only relevant to the situation for new patents. It is most salient for the recent decision under the Copyright Term Extension Act to lengthen the term of copyright protection for 20 years, both for new and existing patents. ${ }^{55}$ That statute was sustained by the Supreme Court in a careful decision of Justice Ginsburg, which paid too much homage to the rational basis test in reaching its decision. ${ }^{56}$ It now makes a real difference what approach is taken to the First Amendment

\footnotetext{
${ }^{55}$ Sonny Bono Copyright Term Extension Act, Pub. L. No. 105-298, 12 Stat. 2827 (1998).

${ }^{56}$ Eldred v. Ashcroft, 537 U.S. 186 (2003), slip op. at 7 ("The Appeals court recognized that this Court has been similarly deferential to the judgment of Congress in the realm of copyright.")
} 
issue. ${ }^{57}$ If the rule is, dogmatically, nothing which is covered by copyright can offend the First Amendment, as the rational basis test can be easily read to imply, the CTEA is home-free without any examination of its content solely because it is a copyright statute. However, the analysis takes a very different view if one asks whether or not there is some social justification for the statute in the sense that it offers gains to others that justify, perhaps to a standard of intermediate scrutiny, the restrictions that have been imposed.

Starting from this perspective, the obvious challenge to the CTEA is that it is a giveaway of public domain property to private individuals, for which the state receives nothing in return. Under the rational basis standard, that giveaway could be justified for the reasons mentioned above, namely, that it facilitates the coherent management of the various brands in question. The Mickey Mouse material might fall into this category in light of the consistent image that Disney has tried to project. This case raises an evident tension between the copyright protection that lapses and the trademark protection that is perpetual. In other cases, such as that of the Gershwin estate, the brand management argument looks still weaker. It is not as though Mozart or Beethoven have suffered because their music is off copyright.

If the level of constitutional scrutiny is ratcheted up, a different set of considerations surely prevails. Once it is clear that the various copyrights fall into the public domain, it is uncertain why they should be given away for free, when they could be resold or licensed to anyone, including their original holders. With this scenario, we could achieve whatever gains are available from brand management, but allow the state to keep some portion of the proceeds through the sale arrangement in ways that honor a

\footnotetext{
${ }^{57}$ See Richard A. Epstein, The Dubious Constitutionality of the Copyright Term Extension Act, 36 LoY. L.A. L. REV. 123, 148-156 (2002).
} 
type of reverse eminent domain clause: nor shall public property be given for private use, without just compensation. ${ }^{58}$ The point is that even if the First Amendment is not offended by this giveaway, some version of the public trust doctrine is. Now is not the time to speak about the uneasy constitutional pedigree of this doctrine at the federal level. It is, however, appropriate to stress that even as a matter of sound policy, the privatization of copyrighted material could be handled by exchange instead of gift.

\section{CONCLUSION}

In sum, when we look at the situation with respect to copyright, it seems clear that the peculiar nature of the rights in question justifies rules that allow for limited duration and fair use, and perhaps some other restrictions. But as such they do not alter the basic tension that exists between liberty and property in the case of labor or natural resources. It is easy to conclude that the foundations of intellectual property law in general and copyright in particular are shaky if it is assumed that the foundations for individual autonomy and private property are secure on some unadorned version of natural law theory that relies more on self-evidence and less on functional advantage. But for years now, my own private campaign has been to insist that the strength of the natural law theories rested on their implicit utilitarian (broadly conceived) foundations, which require some empirical evaluation of why given institutions promote human flourishing and through it general social welfare. Under those tests all legal rules are imperfect adjustments and tradeoffs between competing goods. ${ }^{59}$ Quite simply, any system of private property imposes heavy costs of exclusion. However, these costs can only be

\footnotetext{
${ }^{58}$ Richard A. Epstein, The Public Trust Doctrine, 7 CATO J. 411 (1987). For a discussion of this argument with respect to Eldred, see Richard A. Epstein, The Necessary History of Property and Liberty, Chapman L. Rev. XXX, XXX (2003).

${ }^{59}$ For one of my more recent statements of this view, see Richard A. Epstein, Let "The Fundamental Things Apply": Necessary and Contingent Truths in Legal Scholarship, 115 HARV. L. REV. 1288 (2002).
} 
eliminated by adopting some system of collective ownership that for its part imposes heavy costs of governance. The only choice that we have is to pick the lesser of two evils. There is no magic solution for liberty or property that creates benefits without dislocations. But once we recognize that trade-offs are an inescapable feature of social activity, we could conclude that a sensible system of copyright is not such a bad trade-off after all.

Readers with comments should address them to:

Richard A. Epstein

University of Chicago Law School

1111 East 60th Street

Chicago, IL 60637

repstein@uchicago.edu 


\section{Chicago Working Papers in Law and Economics}

(Second Series)

1. William M. Landes, Copyright Protection of Letters, Diaries and Other Unpublished Works: An Economic Approach (July 1991)

2. Richard A. Epstein, The Path to The T.J. Hooper: The Theory and History of Custom in the Law of Tort (August 1991)

3. Cass R. Sunstein, On Property and Constitutionalism (September 1991)

4. Richard A. Posner, Blackmail, Privacy, and Freedom of Contract (February 1992)

5. Randal C. Picker, Security Interests, Misbehavior, and Common Pools (February 1992)

6. Tomas J. Philipson \& Richard A. Posner, Optimal Regulation of AIDS (April 1992)

7. Douglas G. Baird, Revisiting Auctions in Chapter 11 (April 1992)

8. William M. Landes, Sequential versus Unitary Trials: An Economic Analysis (July 1992)

9. William M. Landes \& Richard A. Posner, The Influence of Economics on Law: A Quantitative Study (August 1992)

10. Alan O. Sykes, The Welfare Economics of Immigration Law: A Theoretical Survey With An Analysis of U.S. Policy (September 1992)

11. Douglas G. Baird, 1992 Katz Lecture: Reconstructing Contracts (November 1992)

12. Gary S. Becker, The Economic Way of Looking at Life (January 1993)

13. J. Mark Ramseyer, Credibly Committing to Efficiency Wages: Cotton Spinning Cartels in Imperial Japan (March 1993)

14. Cass R. Sunstein, Endogenous Preferences, Environmental Law (April 1993)

15. Richard A. Posner, What Do Judges and Justices Maximize? (The Same Thing Everyone Else Does) (April 1993)

16. Lucian Arye Bebchuk and Randal C. Picker, Bankruptcy Rules, Managerial Entrenchment, and Firm-Specific Human Capital (August 1993)

17. J. Mark Ramseyer, Explicit Reasons for Implicit Contracts: The Legal Logic to the Japanese Main Bank System (August 1993)

18. William M. Landes and Richard A. Posner, The Economics of Anticipatory Adjudication (September 1993)

19. Kenneth W. Dam, The Economic Underpinnings of Patent Law (September 1993)

20. Alan O. Sykes, An Introduction to Regression Analysis (October 1993)

21. Richard A. Epstein, The Ubiquity of the Benefit Principle (March 1994)

22. Randal C. Picker, An Introduction to Game Theory and the Law (June 1994)

23. William M. Landes, Counterclaims: An Economic Analysis (June 1994)

24. J. Mark Ramseyer, The Market for Children: Evidence from Early Modern Japan (August 1994)

25. Robert H. Gertner and Geoffrey P. Miller, Settlement Escrows (August 1994)

26. Kenneth W. Dam, Some Economic Considerations in the Intellectual Property Protection of Software (August 1994)

27. Cass R. Sunstein, Rules and Rulelessness, (October 1994) 
28. David Friedman, More Justice for Less Money: A Step Beyond Cimino (December 1994)

29. Daniel Shaviro, Budget Deficits and the Intergenerational Distribution of Lifetime Consumption (January 1995)

30. Douglas G. Baird, The Law and Economics of Contract Damages (February 1995)

31. Daniel Kessler, Thomas Meites, and Geoffrey P. Miller, Explaining Deviations from the Fifty Percent Rule: A Multimodal Approach to the Selection of Cases for Litigation (March 1995)

32. Geoffrey P. Miller, Das Kapital: Solvency Regulation of the American Business Enterprise (April 1995)

33. Richard Craswell, Freedom of Contract (August 1995)

34. J. Mark Ramseyer, Public Choice (November 1995)

35. Kenneth W. Dam, Intellectual Property in an Age of Software and Biotechnology (November 1995)

36. Cass R. Sunstein, Social Norms and Social Roles (January 1996)

37. J. Mark Ramseyer and Eric B. Rasmusen, Judicial Independence in Civil Law Regimes: Econometrics from Japan (January 1996)

38. Richard A. Epstein, Transaction Costs and Property Rights: Or Do Good Fences Make Good Neighbors? (March 1996)

39. Cass R. Sunstein, The Cost-Benefit State (May 1996)

40. William M. Landes and Richard A. Posner, The Economics of Legal Disputes Over the Ownership of Works of Art and Other Collectibles (July 1996)

41. John R. Lott, Jr. and David B. Mustard, Crime, Deterrence, and Right-to-Carry Concealed Handguns (August 1996)

42. Cass R. Sunstein, Health-Health Tradeoffs (September 1996)

43. G. Baird, The Hidden Virtues of Chapter 11: An Overview of the Law and Economics of Financially Distressed Firms (March 1997)

44. Richard A. Posner, Community, Wealth, and Equality (March 1997)

45. William M. Landes, The Art of Law and Economics: An Autobiographical Essay (March 1997)

46. Cass R. Sunstein, Behavioral Analysis of Law (April 1997)

47. John R. Lott, Jr. and Kermit Daniel, Term Limits and Electoral Competitiveness: Evidence from California's State Legislative Races (May 1997)

48. Randal C. Picker, Simple Games in a Complex World: A Generative Approach to the Adoption of Norms (June 1997)

49. Richard A. Epstein, Contracts Small and Contracts Large: Contract Law through the Lens of Laissez-Faire (August 1997)

50. Cass R. Sunstein, Daniel Kahneman, and David Schkade, Assessing Punitive Damages (with Notes on Cognition and Valuation in Law) (December 1997)

51. William M. Landes, Lawrence Lessig, and Michael E. Solimine, Judicial Influence: A Citation Analysis of Federal Courts of Appeals Judges (January 1998)

52. John R. Lott, Jr., A Simple Explanation for Why Campaign Expenditures are Increasing: The Government is Getting Bigger (February 1998) 
53. Richard A. Posner, Values and Consequences: An Introduction to Economic Analysis of Law (March 1998)

54. Denise DiPasquale and Edward L. Glaeser, Incentives and Social Capital: Are Homeowners Better Citizens? (April 1998)

55. Christine Jolls, Cass R. Sunstein, and Richard Thaler, A Behavioral Approach to Law and Economics (May 1998)

56. John R. Lott, Jr., Does a Helping Hand Put Others At Risk?: Affirmative Action, Police Departments, and Crime (May 1998)

57. Cass R. Sunstein and Edna Ullmann-Margalit, Second-Order Decisions (June 1998)

58. Jonathan M. Karpoff and John R. Lott, Jr., Punitive Damages: Their Determinants, Effects on Firm Value, and the Impact of Supreme Court and Congressional Attempts to Limit Awards (July 1998)

59. Kenneth W. Dam, Self-Help in the Digital Jungle (August 1998)

60. John R. Lott, Jr., How Dramatically Did Women's Suffrage Change the Size and Scope of Government? (September 1998)

61. Kevin A. Kordana and Eric A. Posner, A Positive Theory of Chapter 11 (October 1998)

62. David A. Weisbach, Line Drawing, Doctrine, and Efficiency in the Tax Law (November 1998)

63. Jack L. Goldsmith and Eric A. Posner, A Theory of Customary International Law (November 1998)

64. John R. Lott, Jr., Public Schooling, Indoctrination, and Totalitarianism (December 1998)

65. Cass R. Sunstein, Private Broadcasters and the Public Interest: Notes Toward A "Third Way" (January 1999)

66. Richard A. Posner, An Economic Approach to the Law of Evidence (February 1999)

67. Yannis Bakos, Erik Brynjolfsson, Douglas Lichtman, Shared Information Goods (February 1999)

68. Kenneth W. Dam, Intellectual Property and the Academic Enterprise (February 1999)

69. Gertrud M. Fremling and Richard A. Posner, Status Signaling and the Law, with Particular Application to Sexual Harassment (March 1999)

70. Cass R. Sunstein, Must Formalism Be Defended Empirically? (March 1999)

71. Jonathan M. Karpoff, John R. Lott, Jr., and Graeme Rankine, Environmental Violations, Legal Penalties, and Reputation Costs (March 1999)

72. Matthew D. Adler and Eric A. Posner, Rethinking Cost-Benefit Analysis (April 1999)

73. John R. Lott, Jr. and William M. Landes, Multiple Victim Public Shooting, Bombings, and Right-to-Carry Concealed Handgun Laws: Contrasting Private and Public Law Enforcement (April 1999) 
74. Lisa Bernstein, The Questionable Empirical Basis of Article 2's Incorporation Strategy: A Preliminary Study (May 1999)

75. Richard A. Epstein, Deconstructing Privacy: and Putting It Back Together Again (May 1999)

76. William M. Landes, Winning the Art Lottery: The Economic Returns to the Ganz Collection (May 1999)

77. Cass R. Sunstein, David Schkade, and Daniel Kahneman, Do People Want Optimal Deterrence? (June 1999)

78. Tomas J. Philipson and Richard A. Posner, The Long-Run Growth in Obesity as a Function of Technological Change (June 1999)

79. David A. Weisbach, Ironing Out the Flat Tax (August 1999)

80. Eric A. Posner, A Theory of Contract Law under Conditions of Radical Judicial Error (August 1999)

81. David Schkade, Cass R. Sunstein, and Daniel Kahneman, Are Juries Less Erratic than Individuals? Deliberation, Polarization, and Punitive Damages (September 1999)

82. Cass R. Sunstein, Nondelegation Canons (September 1999)

83. Richard A. Posner, The Theory and Practice of Citations Analysis, with Special Reference to Law and Economics (September 1999)

84. Randal C. Picker, Regulating Network Industries: A Look at Intel (October 1999)

85. Cass R. Sunstein, Cognition and Cost-Benefit Analysis (October 1999)

86. Douglas G. Baird and Edward R. Morrison, Optimal Timing and Legal Decisionmaking: The Case of the Liquidation Decision in Bankruptcy (October 1999)

87. Gertrud M. Fremling and Richard A. Posner, Market Signaling of Personal Characteristics (November 1999)

88. Matthew D. Adler and Eric A. Posner, Implementing Cost-Benefit Analysis When Preferences Are Distorted (November 1999)

89. Richard A. Posner, Orwell versus Huxley: Economics, Technology, Privacy, and Satire (November 1999)

90. David A. Weisbach, Should the Tax Law Require Current Accrual of Interest on Derivative Financial Instruments? (December 1999)

91. Cass R. Sunstein, The Law of Group Polarization (December 1999)

92. Eric A. Posner, Agency Models in Law and Economics (January 2000)

93. Karen Eggleston, Eric A. Posner, and Richard Zeckhauser, Simplicity and Complexity in Contracts (January 2000)

94. Douglas G. Baird and Robert K. Rasmussen, Boyd's Legacy and Blackstone's Ghost (February 2000)

95. David Schkade, Cass R. Sunstein, Daniel Kahneman, Deliberating about Dollars: The Severity Shift (February 2000)

96. Richard A. Posner and Eric B. Rasmusen, Creating and Enforcing Norms, with Special Reference to Sanctions (March 2000) 
97. Douglas Lichtman, Property Rights in Emerging Platform Technologies (April 2000)

98. Cass R. Sunstein and Edna Ullmann-Margalit, Solidarity in Consumption (May 2000)

99. David A. Weisbach, An Economic Analysis of Anti-Tax Avoidance Laws (May 2000, revised May 2002)

100. Cass R. Sunstein, Human Behavior and the Law of Work (June 2000)

101. William M. Landes and Richard A. Posner, Harmless Error (June 2000)

102. Robert H. Frank and Cass R. Sunstein, Cost-Benefit Analysis and Relative Position (August 2000)

103. Eric A. Posner, Law and the Emotions (September 2000)

104. Cass R. Sunstein, Cost-Benefit Default Principles (October 2000)

105. Jack Goldsmith and Alan Sykes, The Dormant Commerce Clause and the Internet (November 2000)

106. Richard A. Posner, Antitrust in the New Economy (November 2000)

107. Douglas Lichtman, Scott Baker, and Kate Kraus, Strategic Disclosure in the Patent System (November 2000)

108. Jack L. Goldsmith and Eric A. Posner, Moral and Legal Rhetoric in International Relations: A Rational Choice Perspective (November 2000)

109. William Meadow and Cass R. Sunstein, Statistics, Not Experts (December 2000)

110. Saul Levmore, Conjunction and Aggregation (December 2000)

111. Saul Levmore, Puzzling Stock Options and Compensation Norms (December 2000)

112. Richard A. Epstein and Alan O. Sykes, The Assault on Managed Care: Vicarious Liability, Class Actions and the Patient's Bill of Rights (December 2000)

113. William M. Landes, Copyright, Borrowed Images and Appropriation Art: An Economic Approach (December 2000)

114. Cass R. Sunstein, Switching the Default Rule (January 2001)

115. George G. Triantis, Financial Contract Design in the World of Venture Capital (January 2001)

116. Jack Goldsmith, Statutory Foreign Affairs Preemption (February 2001)

117. Richard Hynes and Eric A. Posner, The Law and Economics of Consumer Finance (February 2001)

118. Cass R. Sunstein, Academic Fads and Fashions (with Special Reference to Law) (March 2001)

119. Eric A. Posner, Controlling Agencies with Cost-Benefit Analysis: A Positive Political Theory Perspective (April 2001)

120. Douglas G. Baird, Does Bogart Still Get Scale? Rights of Publicity in the Digital Age (April 2001)

121. Douglas G. Baird and Robert K. Rasmussen, Control Rights, Priority Rights and the Conceptual Foundations of Corporate Reorganization (April 2001)

122. David A. Weisbach, Ten Truths about Tax Shelters (May 2001) 
123. William M. Landes, What Has the Visual Arts Rights Act of 1990 Accomplished? (May 2001)

124. Cass R. Sunstein, Social and Economic Rights? Lessons from South Africa (May 2001)

125. Christopher Avery, Christine Jolls, Richard A. Posner, and Alvin E. Roth, The Market for Federal Judicial Law Clerks (June 2001)

126. Douglas G. Baird and Edward R. Morrison, Bankruptcy Decision Making (June 2001)

127. Cass R. Sunstein, Regulating Risks after ATA (June 2001)

128. Cass R. Sunstein, The Laws of Fear (June 2001)

129. Richard A. Epstein, In and Out of Public Solution: The Hidden Perils of Property Transfer (July 2001)

130. Randal C. Picker, Pursuing a Remedy in Microsoft: The Declining Need for Centralized Coordination in a Networked World (July 2001)

131. Cass R. Sunstein, Daniel Kahneman, David Schkade, and Ilana Ritov, Predictably Incoherent Judgments (July 2001)

132. Eric A. Posner, Courts Should Not Enforce Government Contracts (August 2001)

133. Lisa Bernstein, Private Commercial Law in the Cotton Industry: Creating Cooperation through Rules, Norms, and Institutions (August 2001)

134. Richard A. Epstein, The Allocation of the Commons: Parking and Stopping on the Commons (August 2001)

135. Cass R. Sunstein, The Arithmetic of Arsenic (September 2001)

136. Eric A. Posner, Richard Hynes, and Anup Malani, The Political Economy of Property Exemption Laws (September 2001)

137. Eric A. Posner and George G. Triantis, Covenants Not to Compete from an Incomplete Contracts Perspective (September 2001)

138. Cass R. Sunstein, Probability Neglect: Emotions, Worst Cases, and Law (November 2001)

139. Randall S. Kroszner and Philip E. Strahan, Throwing Good Money after Bad? Board Connections and Conflicts in Bank Lending (December 2001)

140. Alan O. Sykes, TRIPs, Pharmaceuticals, Developing Countries, and the Doha "Solution" (February 2002)

141. Edna Ullmann-Margalit and Cass R. Sunstein, Inequality and Indignation (February 2002)

142. Daniel N. Shaviro and David A. Weisbach, The Fifth Circuit Gets It Wrong in Compaq v. Commissioner (February 2002) (Published in Tax Notes, January 28, 2002)

143. Warren F. Schwartz and Alan O. Sykes, The Economic Structure of Renegotiation and Dispute Resolution in the WTO/GATT System (March 2002, Journal of Legal Studies 2002)

144. Richard A. Epstein, HIPAA on Privacy: Its Unintended and Intended Consequences (March 2002, forthcoming Cato Journal, summer 2002) 
145. David A. Weisbach, Thinking Outside the Little Boxes (March 2002, Texas Law Review)

146. Eric A. Posner, Economic Analysis of Contract Law after Three Decades: Success or Failure (March 2002)

147. Randal C. Picker, Copyright as Entry Policy: The Case of Digital Distribution (April 2002, The Antitrust Bulletin)

148. David A. Weisbach, Taxes and Torts in the Redistribution of Income (April 2002, Coase Lecture February 2002)

149. Cass R. Sunstein, Beyond the Precautionary Principle (April 2002)

150. Robert W. Hahn and Cass R. Sunstein, A New Executive Order for Improving Federal Regulation? Deeper and Wider Cost-Benefit Analysis (April 2002)

151. Douglas Lichtman, Copyright as a Rule of Evidence (May 2002, updated January 2003)

152. Richard A. Epstein, Steady the Course: Property Rights in Genetic Material (May 2002; revised March 2003)

153. Jack Goldsmith and Cass R. Sunstein, Military Tribunals and Legal Culture: What a Difference Sixty Years Makes (June 2002)

154. William M. Landes and Richard A. Posner, Indefinitely Renewable Copyright (July 2002)

155. Anne Gron and Alan O. Sykes, Terrorism and Insurance Markets: A Role for the Government as Insurer? (July 2002)

156. Cass R. Sunstein and Adrian Vermeule, Interpretation and Institutions (July 2002)

157. Cass R. Sunstein, The Rights of Animals: A Very Short Primer (August 2002)

158. Cass R. Sunstein, Avoiding Absurdity? A New Canon in Regulatory Law (with Notes on Interpretive Theory) (August 2002)

159. Randal C. Picker, From Edison to the Broadcast Flag: Mechanisms of Consent and Refusal and the Propertization of Copyright (September 2002)

160. Eric A. Posner, A Theory of the Laws of War (September 2002)

161 Eric A. Posner, Probability Errors: Some Positive and Normative Implications for Tort and Contract Law (September 2002)

162. Lior Jacob Strahilevitz, Charismatic Code, Social Norms, and the Emergence of Cooperation on the File-Swapping Networks (September 2002)

163. David A. Weisbach, Does the X-Tax Mark the Spot? (September 2002)

164. Cass R. Sunstein, Conformity and Dissent (September 2002)

165. Cass R. Sunstein, Hazardous Heuristics (October 2002)

166. Douglas Lichtman, Uncertainty and the Standard for Preliminary Relief (October 2002)

167. Edward T. Swaine, Rational Custom (November 2002)

168. Julie Roin, Truth in Government: Beyond the Tax Expenditure Budget (November 2002)

169. Avraham D. Tabbach, Criminal Behavior: Sanctions and Income Taxation: An Economic Analysis (November 2002) 
170. Richard A. Epstein, In Defense of "Old" Public Health: The Legal Framework for the Regulation of Public Health (December 2002)

171. Richard A. Epstein, Animals as Objects, or Subjects, of Rights (December 2002)

172. David A. Weisbach, Taxation and Risk-Taking with Multiple Tax Rates (December 2002)

173. Douglas G. Baird and Robert K. Rasmussen, The End of Bankruptcy (December 2002)

174. Richard A. Epstein, Into the Frying Pan: Standing and Privity under the Telecommunications Act of 1996 and Beyond (December 2002)

175. Douglas G. Baird, In Coase's Footsteps (January 2003)

176. David A. Weisbach, Measurement and Tax Depreciation Policy: The Case of Short-Term Assets (January 2003)

177. Randal C. Picker, Understanding Statutory Bundles: Does the Sherman Act Come with the 1996 Telecommunications Act? (January 2003)

178. Douglas Lichtman and Randal C. Picker, Entry Policy in Local Telecommunications: Iowa Utilities and Verizon (January 2003)

179. William Landes and Douglas Lichtman, Indirect Liability for Copyright Infringement: An Economic Perspective (February 2003)

180. Cass R. Sunstein, Moral Heuristics (March 2003)

181. Amitai Aviram, Regulation by Networks (March 2003)

182. Richard A. Epstein, Class Actions: Aggregation, Amplification and Distortion (April 2003)

183. Richard A. Epstein, The "Necessary" History of Property and Liberty (April 2003)

184. Eric A. Posner, Transfer Regulations and Cost-Effectiveness Analysis (April 2003)

185. Cass R. Sunstein and Richard H. Thaler, Libertarian Paternalizm Is Not an Oxymoron (May 2003)

186. Alan O. Sykes, The Economics of WTO Rules on Subsidies and Countervailing Measures (May 2003)

187. Alan O. Sykes, The Safeguards Mess: A Critique of WTO Jurisprudence (May 2003)

188. Alan O. Sykes, International Trade and Human Rights: An Economic Perspective (May 2003)

189. Saul Levmore and Kyle Logue, Insuring against Terrorism - and Crime (June 2003)

190. Richard A. Epstein, Trade Secrets as Private Property: Their Constitutional Protection (June 2003)

191. Cass R. Sunstein, Lives, Life-Years, and Willingness to Pay (June 2003)

192. Amitai Aviram, The Paradox of Spontaneous Formation of Private Legal Systems (July 2003)

193. Robert Cooter and Ariel Porat, Decreasing Liability Contracts (July 2003)

194. David A. Weisbach and Jacob Nussim, The Integration of Tax and Spending Programs (September 2003) 
195. William L. Meadow, Anthony Bell, and Cass R. Sunstein, Statistics, Not Memories: What Was the Standard of Care for Administering Antenatal Steroids to Women in Preterm Labor between 1985 and 2000? (September 2003)

196. Cass R. Sunstein, What Did Lawrence Hold? Of Autonomy, Desuetude, Sexuality, and Marriage (September 2003)

197. Randal C. Picker, The Digital Video Recorder: Unbundling Advertising and Content (September 2003)

198. Cass R. Sunstein, David Schkade, and Lisa Michelle Ellman, Ideological Voting on Federal Courts of Appeals: A Preliminary Investigation (September 2003)

199. Avraham D. Tabbach, The Effects of Taxation on Income Producing Crimes with Variable Leisure Time (October 2003)

200. Douglas Lichtman, Rethinking Prosecution History Estoppel (October 2003)

201. Douglas G. Baird and Robert K. Rasmussen, Chapter 11 at Twilight (October 2003)

202. David A. Weisbach, Corporate Tax Avoidance (January 2004)

203. David A. Weisbach, The (Non)Taxation of Risk (January 2004)

204. Richard A. Epstein, Liberty versus Property? Cracks in the Foundations of Copyright Law (April 2004) 